\title{
Date PItS: Chemical Composition and Sensory Characteristics for DeVelopins Value Added Product
}

\author{
By \\ Shalaby, A. O. \\ Faculty of Specific Education, \\ Mansoura University, Egypt \\ Hanaa F. El-Mehiry \\ Faculty of Specific Education, \\ Mansoura University, Egypt \\ Alaa M.A. Genedy
}

Research Gournal Specific Fducation

Faculty of Specific Fducation

glansoura University

ISSUE NO. 45, JANUARY. 2017

مجلة بعوث التربية النوعية - جامعة المنصورة

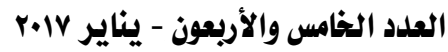




\title{
DATE PItS: Chemical Composition and Sensory Characteristics for DeVelopins Value Added Product
}

\author{
Shalaby, A. O. $\quad$ Hanaa F. El-Mehiry ${ }^{* *} \quad$ Alaa M.A. Genedy
}

\section{Abstract}

Date pits are a major waste product of the date industry that could over potentially valuable richest material for industrial application due to bioactive compounds, and polyphenols, which make it a unique food ingredient. The aim of the present study was to investigate the date pits for their proximate composition, phenolic compound, flavonoid contents and sensory evaluation of date pits products namely (halawa, jam, coffee, and molasses). Chemical composition of date pits showed that content of moisture was $(2.01 \%)$, protein $(5.9 \%)$, fat $(5.8 \%)$, total fiber $(20.07 \%)$, ash $(4.2 \%)$ and carbohydrate $(62.02 \%)$. Date pits was have high content of phenolic compund $(175.45,82.76,61.32,55.56$ and $35.23 \mathrm{mg} / \mathrm{kg}$ ) for gallic acid, chlorogenic acid, ferulic acid, chromatotrophic acid and caffeic acid, respectively. Likewise rich source of flavonoids and phenols contents. Sensory evaluation of (10\% jam, $20 \%$ halawa, $20 \%$ coffee \& $20 \%$ molasses) showed that all were acceptable of eating qualities. Also, results showed that addition of date pits to halawa, coffee and molasses by $20 \%$ improve the nutritive value of products. Thus, these results suggest that date pits can be considered a high nutritive source material for active ingredients for food industrial applications as well as a source of novel approach of nutraceuticals and dietary supplements

Key words: Pheonix Dactylifera; Date Pits; Phenolic Compound, Flavonoids, Molasses; Coffee

\section{Introduction}

Each year, 1.3 billion tons of different wasted food throughout the supply chain could feed as many as two billion people without any additional effect on the environment as specified by FAO. Food waste was

\footnotetext{
* Faculty of Specific Education, Mansoura University, Egypt

Faculty of Specific Education, Mansoura University, Egypt
} 
"one of the great paradoxes of our times", and it is wasting materials to produce food (Scott-Thomas, 2013). Recent research tendency are to explore the use of by-product from food industry, and the waste utilization could supply economic profit to the industry, food security, farmers and for safety of the environment.

The date palm (Phoenix dactylifera L.) is one of the most economically important fruit tree grown in Egypt (Bekheet 2013). Date production of Egypt alone represented about $20 \%$ of the total world production in the year of 2008 (FAO 2010). Although the date palm fruit served as the low cost food for millions of people around the world for several centuries and a large quantity of date seed could be easily collect from the date processing industries or from the waste products originating (Shams-Ardekani et al. 2010). About 11-18\% of the date fruit weight comes from the date pits (Nehdi $\boldsymbol{e t}$ al. 2010). The date pits regarded as an excellent and a rich source of waste product as food ingredients that used in food applications as it an important source of dietary fiber (Besbes $\boldsymbol{e t}$ al. 2009 and Bouaziz et al. 2010). It reported that date pits can be used in human diet as an excellent source of functional foods component (Hamada et al. 2002). Moreover, date seeds powder is used in some conventional medicines that have more concerning for human potential health benefits and enhancing growth (Sabah $\boldsymbol{e t}$ al. 2010). Other studies have also revealed higher amounts of active compounds in date pits as compared to the corresponding flesh (AlFarsi $\boldsymbol{e t}$ al. 2007), increasing the general interest in this waste material and particularly in its potential effect application in the food industry. The nutritional and phytochemical content of date spits from different geographic origins are now well confirmed (Al-Shahib \& Marshall 2002; AlFarsi et al. 2007; Habib \& Ibrahim, 2009). Using date pits in some food application by some rural communities like making cookies which higher in fibre than wheat flour with the same ingredient (Amir et al. 2012), and caffeine-free coffee which can substitute to Arab coffee that it has been presented recently in different markets (Rahman $\boldsymbol{e t}$ al. 2007). Previous research has also shown the possible utilization of date seeds for new product development notions (Mistrello 2013). Since coffee 
drinking is a popular practice in the Arabian region where dates are widely grown, it was postulated that roasting date seeds into coffee-like beverage could represent an alternative product source for those who want to enjoy the characteristic flavor and aroma of coffee without elevateted caffeine intake level (Ghnimi et al. 2015).

Limited research has been conducted on the utilization of date pits for development of high nutritive value products. Thus the purpose of this study is to determine the chemical composition, phenolic compound, and flavonoid and phenols contents of date pits and evaluate the sensory characterizes of some alternative products from date pits powder.

\section{Material and Methods}

\section{Materials:}

The date, kind of Amhat and Zaghool (Phoenix dactylifera L.) were obtained from Local markets. Sugar (sucrose), lemon juice, cinnamon powder, sesame, corn oil, honey, cardamom powder, vanilla, coffee beans powder and water were purchased from local market of different areas in Mansoura city, Egypt.

\section{Methods:}

Preparation of date pits powder: About $5 \mathrm{~kg}$ of seeds was separated from the fruits, soaked in water to remove any residual flesh and air dried for $24 \mathrm{~h}$ at room temperature until the pits color turned. to light brown. The pits were crushed using pestle and mortar followed by high speed laboratory blender, then sieved to obtain finely divided powder, then sieved again to obtain the fine powder (60 mesh).

Preparation of jam: Jam prepared according to the method of Javanmard and Endan (2010). Date pits powder with replaced separately at levels $(10,20 \& 30 \%)$ with date. First of all, dates were added to sugar all the night at fridge. Then the mix of dates and sugar were boiled with lemon juice for 30 minutes to be browner. Date pits powder and cinnamon powder were added to the lasted mix and cooked for 10minutes. Then leaves at room temperature $\left(25 \pm 2^{\circ} \mathrm{C}\right)$ and packed in sterilized jars and stored at fridge temperature $\left(3 \pm 1^{\circ} \mathrm{C}\right)$. 
Preparation of coffee: coffee prepared according to the method of Ghnimi et al. (2015). Date pits powder was replaced with coffee beans powder at levels of $(10,20 \& 30 \%)$ and added sugar to be ready milled with hot water. They were boiled together for a few minutes and filter to get fine coffee.

Preparation of halawa spread: Halawa spread prepared according to the method of Hesham and Zohair (2006). Date pits powder was replaced with sesame at levels of $(10,20 \& 30 \%)$. Sesame was blended very well then corn oil was added to be creamed together. Date pits powder, honey, cardamom powder and vanilla were added to the latest mix. The mix of halawa spread was ready to be packed in sterilized jars and kept in the refrigerator.

Preparation of date pits molasses: molasses were prepared according to the method of Hendrickson and Kesterson (1965). The weighed of date pits powder samples $(10,20 \& 30 \%)$ were boiled in sufficient amount of water for $20 \mathrm{~min}$. The produced date pits molasses was packed in sealed glass bottles and stored at room temperature $\left(20-30^{\circ} \mathrm{C}\right)$.

Proximate determination: Moisture, total protein, fat, ash and total fiber content were carried out according to the methods of A.O.A.C. (2000). Carbohydrates were calculated by the following equation: Carbohydrate = $100-(\%$ Moisture $+\%$ Protein $+\%$ Fat $+\%$ Ash $)$. Energy value was calculated as described by Hawk et al. (1949).

Determination of phenolics and flavonoids content: Phenolic acids and flavonoids, samples were prepared according to the method described by Jakopiè $\boldsymbol{e t}$ al. (2009). The chromatographic conditions were similar to those described by Schieber et al. (2001). A high performance liquid chromatography system equipped with a variable wave length detector (Agilant, Germany) 1100, auto sampler, Quaternary pump degasser and column compartment. Analyses were accomplish on a C18 reverse phase (BDS $5 \mu \mathrm{m}$, Labio, Czech Republic) packed stainlesssteelcolumn $(4 \times 250 \mathrm{~mm})$. All chromatograms were plotted at $280 \mathrm{~nm}$ to appreciated phenolic acids and at $330 \mathrm{~nm}$ for flavonoids. 
Sensory evaluation: Sensory analysis was conducted by twenty panelists recruited among staff members and students of faculty of home economics from Mansoura University, they were asked to express their opinion of prepared products (jam, halawa spread, coffee and molasses). Sensory evaluation of prepared date pits products were carried out according to Moor (1970) which expressed as (10) excellent, (9) very good, (8) good, (7) medium, (6) fair, (5) poor, (4) very poor, (3) extremely poor (Larmond 1977).

\section{Statistically analysis:}

Data were statistically analyzed according to Snedecor and

\section{Cocheran (1980).}

\section{Results and Discussion}

\section{Proximate composition of date pits:}

The nutritional composition of date pits are shown in Table 1 . The moisture content was $2.01 \%$. The protein, fat, ash contents of date pits were $5.9,5.8$ and $4.2 \%$, respectively on dry weight basis. The obtained results indicate that date pits contain relatively high levels of protein, fat, ash, carbohydrates and energy which consider a major cause of quality. These results were similarly to earlier literatures by (Hamada et al. 2002 \& Souhail et al. 2004). Also with of (Al-Farsi and Lee 2007) who studied the functional activites of date pits and reported that composition was 2.30$6.40 \%$ for protein, $5.00-13.20$ for fat and $22.50-80.20 \%$ for fiber. The difference in data related to different date varieties, different harvesting time, different origin and the use of fertilizer kind that could affect the nutrient quality of date pits (Nehdi et al. 2010). 
- Date Pits: Chemical Composition and Sensory Characteristics for Developins Value Added Product

Table 1: Chemical composition of date pits powder in $(\mathrm{mg} / 100 \mathrm{~g} \mathrm{~d} . \mathrm{w})$

\begin{tabular}{|c|c||}
\hline Attributes & $\%$ \\
\hline \hline Moisture & 2.01 \\
\hline Total protein & 5.9 \\
\hline Fat & 5.8 \\
\hline Ash & 4.2 \\
\hline Total fiber & 20.07 \\
\hline Carbohydrates & 62.2 \\
\hline Energy & 404.16 \\
\hline
\end{tabular}

\section{Phenolic compounds in date pits powder:}

Ten phenolic compounds of date pit powder were identified and recorded in Table 2, date pit powder contained considerable amount of phenolic compound with an average from $(8.14$ to $175.45 \mathrm{mg} / \mathrm{kg})$. Results showed that date pits powder recorded (175.45, 82.76, 61.32, 55.56 and $35.23 \mathrm{mg} / \mathrm{kg}$ ) for gallic acid, chlorogenic acid, ferulic acid, chromatotrophic acid and caffeic acid, respectively. These results in agreement with Marimuthu et al. (2007) stated that ferulic acid had a wide range of therapeutic effects against various diseases like diabetes, cancer, neurodegenerative and cardiovascular diseases, due to its strong antioxidant property. Ferulic acid is an effective scavenger of free radicals and it has been approved in certain countries as food additive to protect from lipid peroxidation. Also Mansouri et al. (2012) and Valizadeh et al. (2012) suggested that oral administration of gallic acid has antioxidative activity in brain of rats with experimental neurodegenerative disorders such as Parkinson's and Alzheimer's diseases. Furthermore Abdelaziz et al. (2015) observed that HPLC chromatograms of date seed extracts identified five phenolic compounds (gallic acid, vanillic acid, quercitin, caffeic acid and pcoumaric acid). 
مجلة بحوث التربية النوعية - علد 0؛ - يناير r. r P

Table 2: The concentrations of phenolic compound by high performance liquid chromatography (HPLC) of roasted date pit powder $(\mathrm{mg} / \mathrm{kg})$

\begin{tabular}{|c|c|}
\hline Components & $(\mathrm{mg} / \mathrm{kg})$ \\
\hline \hline Chromatotrophic acid & 55.56 \\
\hline Quercetin & 13.34 \\
\hline Gallic acid & 175.45 \\
\hline p-coumeric acid & 10.67 \\
\hline m-coumeric acid & 15.45 \\
\hline Caffeic acid & 35.23 \\
\hline Chlorogenic acid & $\mathbf{8 2 . 7 6}$ \\
\hline Syringic acid & 8.14 \\
\hline Ferulic acid & 61.32 \\
\hline Vitamin C & 25.09 \\
\hline
\end{tabular}

Data presented in Table 3 showed that date pits had a high content of phenols, which recorded $(57.99,37.47,37.24$ and $36.85 \mathrm{mg} / 100 \mathrm{~g}$ ) for pyrogallol, cinnamic, benzoic and elagic respectively and being the major constitutes of phenol compounds. These components were confirmed with the results of Al-Farsi et al. (2008) and Ammar et al. (2009) who detected that phenolic acids was in date seed such as gallic acid, protocatechuic acid, p-hydroxybenzoic acid, vanillic acid, caffeic acid, p-coumaric acid, ferulic acid, m-coumaric acid and o-coumaric acid. Moreover (Inoue et al. 2009) reported that a chlorogenic acid active compound reduces the risk of cancer and acting as anti-tumor with daily intake of 3 cups or more of coffee. In addition Dalia et al. (2014) reported that date pits can be used as successful ingredient to various food sectors for its nutritional value, cytotoxicactivity and anti-carcinogenic effect. 
- Date Pits: Chemical Composition and Sensory Characteristics for Developins Value Added Product

Table 3: Concentrations of phenols in roasted date pits (mg/100g) by HPLC analysis

\begin{tabular}{|c|c||}
\hline Components & $(\mathrm{mg} / \mathrm{kg})$ \\
\hline \hline Pyrogallol & 57.99 \\
\hline Benzoic & 37.24 \\
\hline Cinnamic & 37.47 \\
\hline Elagic & 36.85 \\
\hline Catechol & 22.58 \\
\hline Protocatchoic, & 17.87 \\
\hline Syringic & 15.54 \\
\hline Caffeine & 6.22 \\
\hline Vanillic & 6.14 \\
\hline Epicatechin & 4.47 \\
\hline Chlorogenic & 4.87 \\
\hline P-OH-Benzoic & 4.96 \\
\hline Ferulic & 4.21 \\
\hline \hline
\end{tabular}

Nine flavonoids from date pits were identified as presented in Table 4. Data indicated considerable amount of flavonoids compound with an average from ( 18.27 to $0.45 \mathrm{mg} / \mathrm{kg}$ ). Results showed that date pits powder recorded $(18.27,8.70$ and $3.39 \mathrm{mg} / 100 \mathrm{~g})$ for hesperdin, narengin and rutin, respectively. Hesperdin was the major flavonoid component. Our results revealed that the date pits contain high amount of flavonoid wich confer health benfits as antioxidant radical scavenging properties. These results similarly with the finding of Dalia et al. (2014) evaluated roasted date pits and indicated that hesperdin was the major flavonoids. Furthermore (Banerjee et al. 2008) suggested that date pit at concentration $100 \mu \mathrm{l} / \mathrm{ml}$ was effective against human colon cancer cell line in vitro and have anticarcinogenic effect and linked that with isoflavonoid found in it with potential estrogenic activity.

Finally, this approach can be used to execute the recovery and consecutive industrial processing of date pits as natural source of these 
compounds with unlimited potentials in food applications. Flavonoids are in fact linked with potential bioactive properties (Heim et al. 2002; Ross \& Kasum 2002). Their effective use as natural colorings has been reported in various studies (Bridle \& Timberlake 1997 \& Galleano et al. 2010), antioxidants properties in food sectors (Kranl et al. 2005 \& Castro 2009), and antibacterial agents (Xu \& Lee 2001 and Cushnie \& Lamb 2005). In these concepts, common and different technological methods should be used to develop new functional ingredients from date pits, that containing phenolic compounds and flavonoids with antioxidants activities.

Table 4: Flavonoids identification of roasted date pits (mg/100g) by HPLC analysis

\begin{tabular}{||c|c||}
\hline Components & $(\mathrm{mg} / \mathrm{kg})$ \\
\hline \hline Hesperdin & 18.27 \\
\hline Narengin & 8.70 \\
\hline Rutin & 3.39 \\
\hline Hespertin & 2.12 \\
\hline 7-hydroxy flavon & 0.67 \\
\hline Kaempferol & 1.38 \\
\hline Quercetin & 1.05 \\
\hline Rosmarinic & 0.74 \\
\hline Narenginin & 0.45 \\
\hline
\end{tabular}

\section{Sensory evaluation:}

Sensory characteristics of different products namely jam, coffee, halawa spread and molasses as affected by adding different levels $(10,20 \&$ $30 \%$ ) of date pits powder are presented in Table 5. All samples prepared of $20 \%$ date pits powder had relatively high value of taste, odor, color and overall acceptability. Meanwhile added 30\% date pits powder in (halawa, coffee and molasses) recorded the lowest scores for taste, order, texture, color and over all acceptability. Thus the samples of $20 \%$ substitution of date pits powder are the best according to sensory evaluation for all products except jam, the best addition of date pits to jam was $10 \%$ had the highest 
scores for taste, order, texture, color and over all acceptability. The results of sensory evaluation suggest that the date pits phenolic compounds can be successfully used as natural antioxidant in some food products. The results in the same line with the finding of Hamada et al. (2002) suggested that date pits can be used in foods as an inexpensive source of dietary fiber and other functional components. Moreover Mohamed et al. (2012) reported that addition of date pits to jam enhance color and flavor.

Table 5: Effect of using date pits on sensory evaluation of processing some products with different levels of date pits

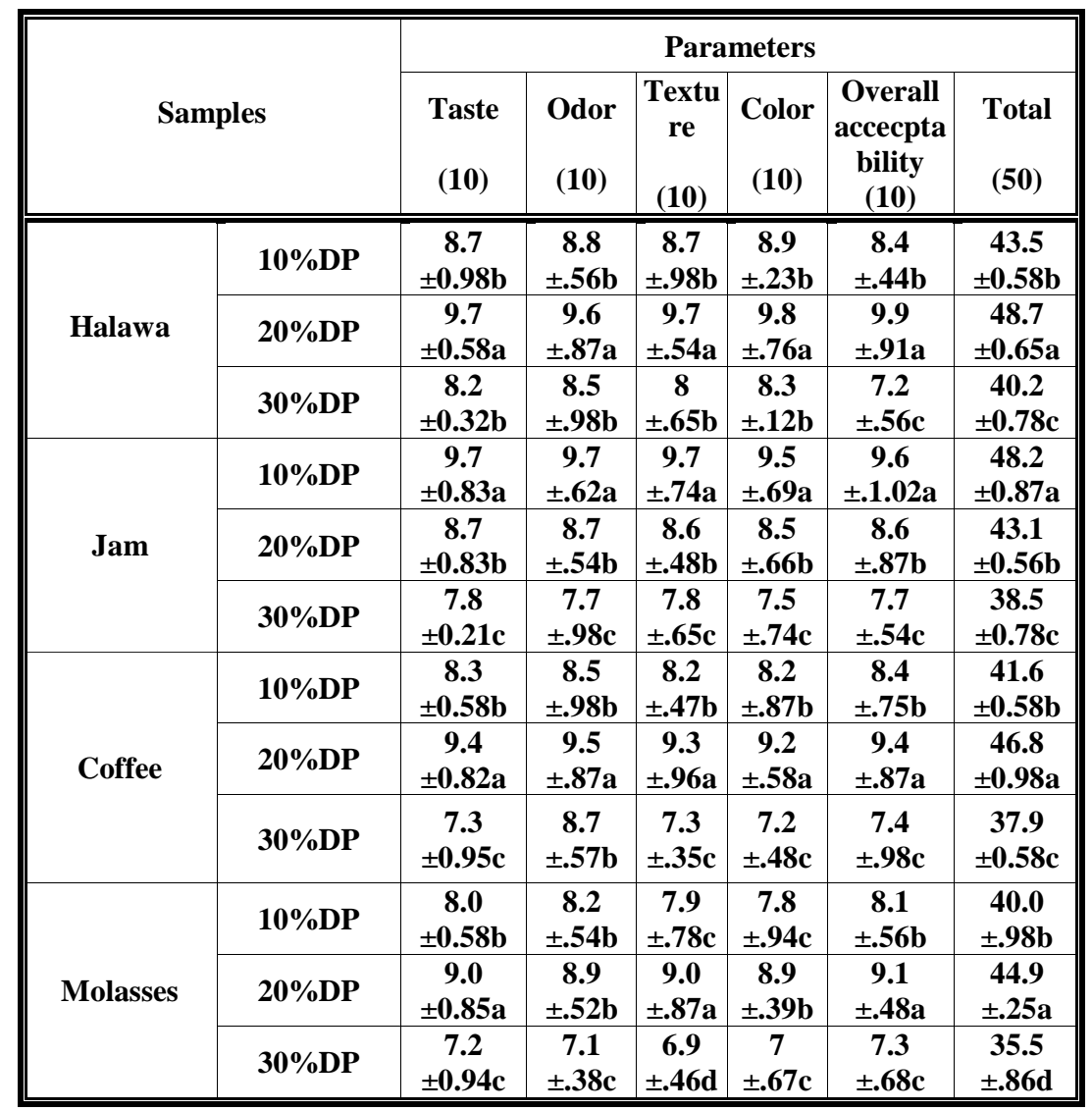

DP: date pits, Mean values in each column having different subscript (a, b, c, d, ) are significantly different at $\mathrm{P}<0.05$. 


\section{Proximate chemical composition of best chosen date pits products:}

The chemical composition (moisture, total protein, ash, fat, carbohydrates and energy) of the best addition levels of date pits for preparing (halawa, jam, coffee and molasses) samples according to sensory evaluation are shown in Table 6. Results showed that moisture content ranged from (13.85 to $44.87 \%$ ) the highest moisture percentage (44.87\%) was for date pits molasses and the lowest content (13.85\%) was for date pits halawa. Results similarly with reports of Amir et al. (2012) reported the moisture content increases with the increase of addition of date pits in some products. Significant differences were observed between samples in the protein content and fat (g/100w.w) which ranged from (1.26 to 14.12\%) and (2.67 to $13.96 \%)$. Date pits jam gained the highest protein content $(14.12 \%)$ followed by halawa (11.87\%) and then coffee $(8.03 \%)$, while the lowest protein content $(1.26 \%)$ was for molasses. Data also show that ash content was ranged from (1.75 to $17.04 \%$ ) in prepared products, $10 \%$ jam recorded that the highest ash content (17.04\%) followed by $20 \%$ molasses (11.03\%); however the lowest ash content (1.75\%) for 20\% coffee. On the other hand carbohydrates content ranged from (17.2\% to 46.2\%). Also total fibers content ranged from (14.73 to $28.04 \%)$. The highest content $(28.04 \%)$ was for jam and the lowest content (14.73\%) was for $20 \%$ date pits molasses. on the other hand, energy recorded $(406.2,262.07,261.74$ and 195.75) for Halawa spread, Jam, coffee and molasses respectively.

Generally, it could be observed from Table 6 that the addition of date pits powder to the products of halawa spread, jam, coffee and molasses at level of 10 and $20 \%$ increased total content of fibers, protein, carbohydrates, ash and energy. These results are in parallel with Mohamed et al. (2012) stated that date pits can be used as an alternative source of dietary fiber and suggested using date pits as a high value-added component and a functional material in food applications. Furthermore Leon $\boldsymbol{e t}$ al. (2012) reported that seeds of dates can be used as useful healthy drinks like coffee without using expensive materials. 
- Date Pits: Chemical Composition and Sensory Characteristics for Developins Value Added Product

Table 6: Chemical composition of date pits products in $(\mathrm{mg} / 100 \mathrm{~g}$ wet matter)

\begin{tabular}{||c|c|c|c|c||}
\hline Samples & $\begin{array}{c}\text { Halawa spread } \\
20 \% \text { DP }\end{array}$ & $\begin{array}{c}\text { Jam } \\
10 \% \text { DP }\end{array}$ & $\begin{array}{c}\text { Coffee } \\
20 \% \text { DP }\end{array}$ & $\begin{array}{c}\text { Molasses } \\
20 \% \text { DP }\end{array}$ \\
\hline \hline Parameters & 13.85 & 20.93 & 24.79 & 44.87 \\
\hline Moisture & 11.87 & 14.12 & 8.03 & 1.26 \\
\hline Total protein & 13.96 & 2.67 & 3.24 & 3.87 \\
\hline Fat & 2.05 & 17.04 & 1.75 & 11.03 \\
\hline Ash & 22.77 & 28.04 & 15.99 & 14.73 \\
\hline Total fiber & 35.5 & 17.2 & 46.2 & 24.24 \\
\hline Carbohydrates & 406.2 & 261.47 & 262.07 & 195.75 \\
\hline \hline
\end{tabular}

DP: date pits

\section{Conclusion}

The current study improves our knowledge of the nutritional value of date pits, and supports their effect use depending on chemical composition, phenolic compound and sensory evaluation of date pits powder in some products as natural, active ingredients for food applications. It concluded that date pits by-product a valuable and a rich source of functional food component with low cost. Data illustrated that date pits powder contain high active components such as flavonoids and phenols which increase the antioxidant activity. The suitable concentration of using date pits powder in some products to enhance food quality should be assessed on food systems using more new techniques. In addition, the future commercial application of such fruits wastes as nutraceuticals materials or dietary supplements needed.

\section{Recommendation}

According to the results of this study, the researcher recommended the following:

1. Utilization of date pits powder in home processed food products such as halawa spread, jam, coffee and molasses as a source of antioxidants to maintain a good health and protect from diseases. 
2. Using of date pits powder as a source of phytochemicals and antioxidants at levels of $10 \%$ in halawa spread, coffee molasses and $20 \%$ in jam products is suitable in acceptability and give high nutritional quality.

3. The consumption of date pits products improve and enhance the health status of heart patients, thus Enter the fruit in manufacturing pharmaceutical as therapy is recommended.

4. More studies should be carried out to study the effects of flavonoids, polyphenols and tannins fraction of date pits on their therapeutical value.

\section{References}

- (Phoenix dactylifera, L.). Ghnimi et al., J Food Process Technol 2015, 6:12A.A.C.C. 2000. Approved Method of the AACC. $10^{\text {th }}$ ed., American association of Cereal Chemists, INC. St., Paul, Minnesota, USA.

- A.A.C.C. 2000. Approved Method of the AACC. $10^{\text {th }}$ ed., American association of Cereal Chemists, INC. St., Paul, Minnesota, USA.

- Abdelaziz, M. H.; A. M.D. El-Mousalamy; S. A. M. Hussein and S. A. Mahmoud, 2015. Effects of palm dates (phoenix dactylifera 1) extracts on hepatic dysfunctions in type 2 diabetic rat model. World journal of pharmacy and pharmaceutical sciences. Issue 07, 62-79.

- Al Farsi, M.A. and C.Y. Lee, 2008. Nutritional and functional properties of dates: a review Critical Reviews. Food Sci Nutr 2008; 48:877-887.

- Al-Farsi, C. A; M. A. I Abid; K. Al-Shoaily; M. Al-Amry, and F. AlRawahy, 2007. Compositional and functional characteristics of dates, syrups, and their by-products. Food Chemistry, 104, 943-947.

- Al-shahib, W., and R. J. Marshall, 2002. Dietary fibre content of dates from 13 varieties of date palm Phoenx dactylifera L. International Journal of Food Science and Technology, 37, 719-721.

- Amir I. Z. and H.J.I. Wei, 2012. Development and physicochemical properties of cookies incorporated with Date seed powder. International Annual Symposium on Sustainability Science and Management, 93 (2): 978- 967. 
- Date Pits: Chemical Composition and Sensory Characteristics for Developins Value Added Product

- Ammar, N.M; S.Y. Al-Okbi; D.A. Mohamed and L.T.A. EL-Kassem, 2009. Antioxidant and Estrogen like Activity of the Seed Phoenix dactylifera L. Palm growing in Egyptian Oases. Science pub, 1(3): 1-8.

- Banerjee, S; Yiwei Li; Zhiwei Wang and Fazlul H. Sarkar, 2008. Multitargeted therapy of cancer by genistein. Cancer Letters, Vol. 269 No. 2, pp. 226242.

- Bekheet, S., 2013. Date palm biotechnology in Egypt. App. Sci. Report, 3: 144152.

- Besbes, S.; L. Drira; C. Blecker; C. Deroanne and H. Attia, 2009. Adding value to hard date (Phoenix dactylifera L.): Compositional, functional and sensory characteristics of date jam. Food Chem., 112: 406-411.

- Bouaziz, M.A.; H.B. Amara; H. Attia; C.H. Blecker, and S. Besbes, 2010. Effect of the addition of defatted date seeds on wheat dough performance and bread quality. J. Text. Stud. 41 (4), 511-531.

- Bridle, P, and C. Timberlake, 1997. Anthocyanins as natural food colours selected aspects. Food Chemistry, 58(1-2), 103-109.

- Cushnie, T., and A. Lamb, 2005. Antimicrobial activity of flavonoids. International Journal of Antimicrobial Agents, 26(5), 343- 356.

- Dalia M. E.; E. A. El- Kholany and S. M. Kamel, 2014. Nutritional Value, Cytotoxicity, Anti-Carcinogenic and Beverage Evaluation of Roasted Date Pits. World Journal of Dairy \& Food Sciences 9 (2): 308-316.

- Eldin A (2015): Quality Evaluation of Coffee-Like Beverage from Date Seeds

- FAO, 2010. Statistical databases. http://faostat.fao.org Accessed June 2010.

- Galleano, M.; S.V. Verstraenten; P.I. Oteiza, and C.G. Fraga, 2010. Antioxidant actions of flavonoids: Thermodinamic and kinetic analysis. Archives of Biochemistry and Biophysics, 501, 23-30.

- Ghnimi, S; R. Almansoori; B. Jobe; M.H. Hassan and A. Kamal-Eldin , 2015. Quality Evaluation of Coffee-Like Beverage from Date Seeds (Phoenix dactylifera, L.). J Food Process Technol 6: 525.

- Hamada, J. S.; I.B. Hashim, and A.F. Sharif, 2002. Preliminary analysis and potential uses of date pits in foods. Food Chem. 76, 135-137. 
- Hawk, P .D.; B.L. Oser, and W.H. Summerson, 1949. Practical physiology chemistry. J. Nutrition, 12:962.

- Heim, K.; A. Tagliaferro, and D. Bobilya, 2002. Flavonoid antioxidants: chemistry, metabolism and structure-activity relationships. Journal of Nutritional Biochemistry, 13(10), 572-584.

- Hendrickson, R. and J.W. Kesterson. 1965. By-products of Florida citrus: Composition, technology and utilization. Fla. Agr. Exp. Sta. Bull. 698.

- Hesham, A. E., and A. Zohair, 2006. Quality and safety of halawa modified with mushroomJ Sci Food Agric 86:2551-2559.

- Inoue M.; N. Kurahashi; M. Iwasaki; T. Shimazu; Y. Tanaka ; M.

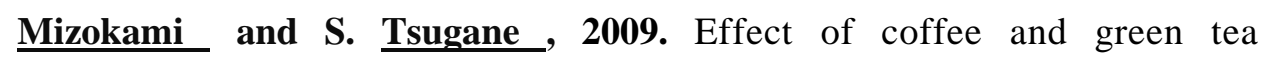
consumption on the risk of liver cancer: cohort analysis by hepatitis virus infection status. Cancer Epidemiol. Biomarkers Prev.18, 1746-53.

- Hesham A Eissa and Azza Zohair (2006): Quality and safety of halawa modified

- Hesham A Eissa and Azza Zohair (2006): Quality and safety of halawa modified

- Jakopiè, J.; R. Veberiè and F. Štampar, 2009. Extraction of phenolic compounds from green walnut fruitsin different solvents. Actaagriculturae Slovenica, 93: 11-15.

- Javanmard, M., and J.Endan, 2010. A survey on rheological properties of fruit jams. International Journal of Chemical Engineering and Applications, 1(1):3137.

- Kranl, K; K. Schlesier; R. Bitsch; H. Hermann; M. Rohe, and V. Bohm, 2005. Comparing antioxidative food additives and secondary plant products use of different assays. Food Chemistry, 93(1), 171-175.

- Larmond, E., 1977. Laboratory methods for sensory evaluation of food. Publication 1637. Ottawa: Food Research Institute.

- Leon, A. A, and M. Andriani, 2012. Friendly alternative healthy drinks through the use of date seeds as coffee powder. Proceeding of ICEBM-Untar Jakarta-ISBN: 978-602-18994-0-3.

- Mansouri, M.T.; Y. Farbood; S.M. Jafar; A. Sarkaki; B. Naghizadeh and M. Rafeirad, 2012. Neuroprotective effects of oral gallic acid against oxidative stress induced by 6-hydroxydopamine in rats. Food Chemistry, 138: 1028-1033. 
- Date Pits: Chemical Composition and Sensory Characteristics for Developins Value Added Product

- Marimuthu, S.; R. A. Sudheer, and P.M. Venugopal, 2007. Ferulic Acid: Therapeutic potential through its antioxidant property. J Clin Biochem Nutr. 2007 Mar; 40(2): 92-100.

- Mistrello, J. , 2013. Date seeds: functional ingredient for npd. Food Science and Technology Journal, 26(4), 10-12.

- Mohamed, E.S.; M. A. Al-Mamun; J. I. Daoud and S. M. Mustafa, 2012. Processing of Date Palm Kernel (Dpk) for production of edible jam. Australian Journal of Basic and Applied Sciences, 6(1): 22-29, 2012.

- Moor, M. L., 1970. Introducing foods , laboratory manual of food preparation and evaluation. $2^{\text {nd }}$ ED. MacMillan. pub. Co. Inc., New York, Coclier, London.

- Nehdi, I.; S. Omri; M.I. Khalil and S.I. Al-Resayes, 2010. Characteristics and chemical composition of date palm (Pheonixcanariensis) seeds and seeds oil. Industrial Crops and Products, 32: 360-365.

- Rahman M.S.; S. Kasapis; N.S.Z. Al-Kharusi; I.M. Al-Marhubi and A.J. Khan, 2007. Composition characterization and thermal transition of date pits powders. J. Food Eng., 80, 1-10.

- Ross, J., and C. Kasum, 2002. Dietary flavonoids: bioavailability, metabolic effects, and safety. Annual Review of Nutrition, 22, 19-34.

- Sabah,A.; Jassim,A. and Naji,M. 2010. In vitro evaluation of the antiviral activity of an extract of date palm (Phoenix dactylifera L.) pits on a pseudomonas phage. Evid Based Complement Alternat Med. 7(1): 57-62.

- Schieber, A.; P. Keller and R. Carle, 2001. Determination of phenolic acids and flavonoids of apple and pear by high-performance liquid chromatography. J. Chromatography A, 910: 265-273.

- Scott-Thomas C., 2013. Food waste one of the great paradoxes of our times. [http://www.foodnavigator.com] (accessed 17 October 2013).

- Shams-Ardekani, M.R.; M. Khanavi; M. Hajima Hmoodi; M. Jahangiri and A. Hadjiakhoondi, 2010. Comparison of antioxidant activity and total phenol contents of some date's seed varieties from Iran. Iranian J. Pharm. Res., 9: 141-146.

- Snedecor, G.W., and W.G. Cochran, 1967. Statistical Methods; 7th Ed., The Lowa State University Press., Ames, Lowa, U.S.A. 
مجلة بحوث التربية النوعية - علد 0؛ - بيناير $\quad$ م.lv

- Souhail, B.; C. Bleckerb; C. Deroanneb; D. Nour-Eddine and H. Attiaa, 2004. Date seeds: Chemical composition and characteristic profiles of the lipid fraction. Food Chemistry 84 (2004) 577-584

- Valizadeh, Z.; A. Eidi; A. Sarkaki; Y. Farbood and P. Motrtazavi, 2012. Dementia type of Alzheimer's disease due to beta-amyloid wad improved by gallic acid in rats. Health Med, 6: 3648-3657

- Xu, H., and S. Lee, 2001. Activity of plant flavonoids against antibioticresistant bacteria. Phytotherapy Research, 15(1), 39-43 


\section{نوى البلح :التركيب الكيسيائي والذصائص الصسية}

\section{لتطوير هنتجات عالية القيهة الغذائية}

الاء بجدىجنيدى

$$
\text { هناء فاروق المهيريـ }
$$

أحمد عثمازشليــ

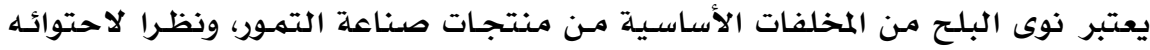

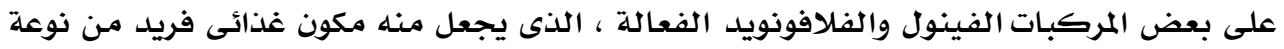

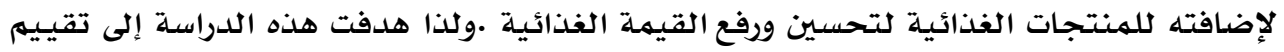

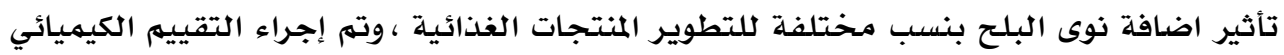

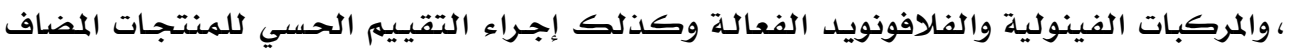

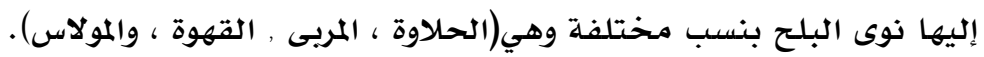

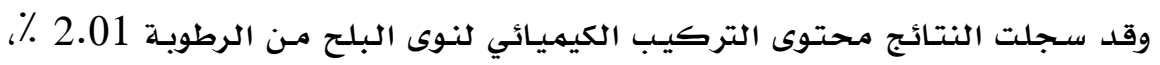

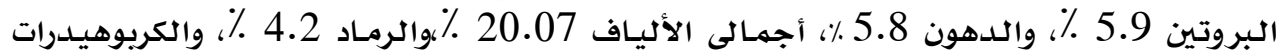

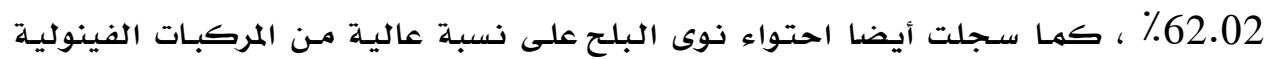

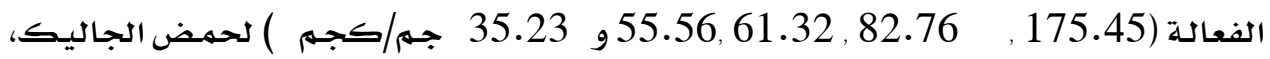

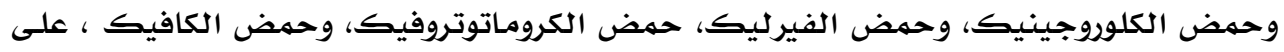

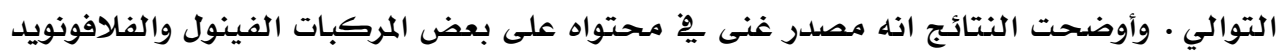

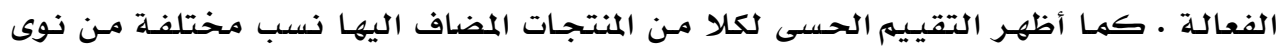

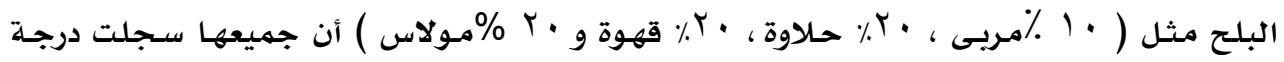

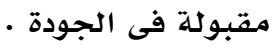

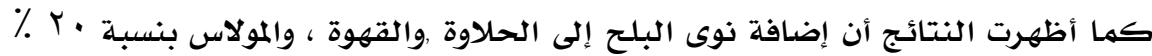

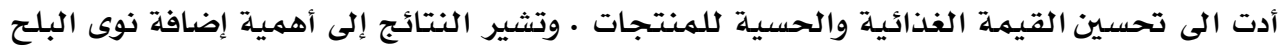

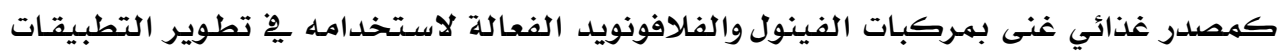

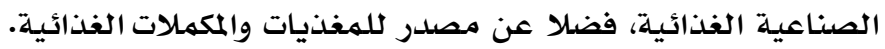

* قسه الاقتصاد المنزلى - كلية تربية نوعية - جامعة المنصورة

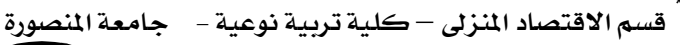

